\title{
Fishers' perceptions as indicators of the performance of Marine Protected Areas (MPAs)
}

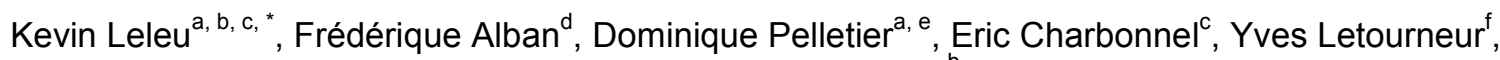 \\ Charles F. Boudouresque ${ }^{b}$
}

\author{
a IFREMER Brest, BP 70. 29280 Plouzané, France \\ b Mediterranean Institute of Oceanography, University of the Mediterranean, Campus de Luminy, Case 901, \\ 13288 Marseille Cedex, France \\ c Parc Marin de la Côte Bleue, Observatoire-plage du Rouet, 31 Avenue Jean Bart, B.P 42, 13620 Carry-le- \\ Rouet, France \\ d Université de Brest, UEB, UMR AMURE, 12 rue du Kergoat, CS 93837, 29238 Brest Cedex 3, France \\ e IFREMER Nouvelle Calédonie, BP 2059, 98846 Nouméa Cedex, New Caledonia, France \\ f Université de la Nouvelle Calédonie, Laboratoire LIVE, Campus de Nouville, BP R4, 98851 Nouméa Cedex, \\ New Caledonia, France
}

\author{
*: Corresponding author : Kevin Leleu ; +33491829067; fax: +33491411265. \\ email address : kevin.leleu@ifremer.fr ; kevin.leleu@univmed.fr
}

\begin{abstract}
:
How users perceive the performance of Marine Protected Areas (MPAs) is fundamental for the social acceptance of these zones. Moreover, their perceptions may be relevant for monitoring the effects of MPAs on extractive activities. This study analyzes artisanal fishers' perceptions of the performance of a north-western Mediterranean coastal MPA, which encompasses two no-take zones (NTZs). Three viewpoints have been considered: the effect on the personal activity of fishers, the effect on the local fishery and the effect on the ecosystem. In order to test the hypothesis that biomass export (spillover) - which had previously been evidenced from the two NTZs - may influence fishers' perceptions of NTZ effects, fishers' perceptions were compared with both declared and observed fishing activity over an one-year period.
\end{abstract}

The results show that negative perceptions of NTZs are either nil or are negligible. Most fishers are aware of the beneficial effects of NTZs on ecosystems and fisheries. However, they remain to be convinced of the beneficial effects of the NTZs on their own activity. For instance, the proximity of a NTZ appears never to be involved in the choice of a fishing spot. This partial lack of correspondence between scientific expectation and fishers' perceptions is discussed in the light of fishing habits in the zone adjacent to NTZs, and takes into account fishing grounds, targeted species and seniority (defined as the number of years the fisher has been fishing within the MPA). All three factors appear to influence fishers' perceptions. For example, having a positive perception about a NTZ and spending more time fishing in the adjacent zone are habits that can be associated with fishers with less seniority. Fishers' perceptions obviously indicate the social acceptance of the MPA and are an essential monitoring tool for MPA managers. However, perceptions cannot be seen as a substitute for 
scientific monitoring, as both approaches are clearly complementary.

\section{Highlights}

Fishers' perceptions of MPAs play a key role in the social acceptance of these zones. No negative perception was expressed by artisanal fishers of the MPA. General benefits from the MPA are better perceived than personal benefits. Mismatch appears between fishers' perceptions and scientific expectations.

Keywords: Artisanal fishery ; Fishers' perceptions ; Social acceptance ; No-take zone ; MPA performance

\section{Introduction}

There is now increasing evidence that Marine Protected Areas (MPAs) have beneficial effects on marine resources and yields when they are associated with no-take zones (NTZs), 
artificial reefs and/or with other fishing regulations [1-6]. In particular, NTZs appear to be beneficial for fisheries via (i) increased export of eggs and larvae resulting from improved spawning success within the NTZ [7-8], and (ii) export of biomass towards adjacent zones (spillover), which is defined as the progressive diminution of fish numbers and/or biomass between the NTZ boundary and distant unprotected areas [9-13]. The magnitude of these effects appears to be dependent on the size and age of the NTZ [14], on life history traits and ecology of fish species [15], as well as on habitat connectivity and continuity between the NTZ habitats, adjacent habitats and other MPAs [16-20]. The effects of NTZs upon fisheries have been monitored using both non extractive techniques (e.g. underwater visual censuses [21]; see [22] and references therein) and extractive observation techniques (e.g. experimental fishing and fishery statistics; see [13, 23-25]). Concentration of the fishing effort close to the boundaries of NTZs has sometimes been used as an indirect indicator of the beneficial effects of marine NTZs [26-27] (but see also [28-30]).

In contrast, there is a lack of data available concerning investigations into fishers' perceptions of the effects of NTZs and MPAs. These effects, nevertheless, are often highlighted by policy makers and managers for the promotion of these tools [31-32]. Several studies have dealt with stakeholders' (including fishers') perceptions and attitudes towards fisheries and MPA management and with their social and economic impact locally, especially in coral reef habitats [33-41]. Based on correlations between scientific results and fishers' perceptions, the latter have at times been considered as a useful indicator in the tracking of resource changes over space and time [42-47], even if distrust between scientists and fishers remains pervasive [47-49]. Perceptions may be influenced by several factors independent of NTZ effects, such as the social context of the MPA territory, the MPA management [50-51] or the behavior justification by stakeholders (as expressed by Boltanski et Thevenot [52]). However, these biases may not be significant in cases of high compliance with MPA management [53].

This study first aimed at testing the value of fishers' perceptions as indicators of social acceptance and compliance in the case of a north-western Mediterranean MPA, the Parc Marin de la Côte Bleue (PMCB). For the two NTZs of this 27-year old MPA, biomass exports have been demonstrated, although differences have been observed depending on species [5458]. It was thus assumed that (i) biomass export (spillover) was more likely to be perceived by artisanal (small-scale coastal) fishers than was larval export [6]; and (ii) this spillover could be detected by fishers operating within the zone adjacent to the NTZs [56, 59]. For this reason, the suitability of fishers' perceptions in the monitoring of NTZ effects was 
investigated. The assumption that these perceptions depend on both the species targeted and on the frequency of fishing trips within the zone adjacent to the NTZs was also analyzed. It was expected that fishers who perceive positive NTZ effects on their own activity would wish to increase the frequency of their fishing trips near the NTZs.

\section{Material and methods}

\subsection{Study area}

The Parc Marin de la Côte Bleue (PMCB) is a 9873 ha MPA located in the northwestern Mediterranean Sea (Provence, France), (Fig. 1). This MPA includes two NTZs, namely Carry-le-Rouet (92 ha; hereafter referred to as Carry) and Cap Couronne (198 ha; hereafter called Couronne), established in 1983 and 1996, respectively (Table 1). In addition to bans on fishing and harvesting, scuba diving and anchoring are also forbidden in both NTZs. Outside the NTZs, artisanal fishing is managed through European Union regulations (e.g. fishing net length), French national regulations (e.g. minimum catch size), and local regulations (e.g. mesh size) as established by the prud'homies des pêcheurs (fishers' guilds) of Marseille and Martigues. According to French regulations, trawling within $\sim 5.6 \mathrm{~km}$ from the shore (an area which includes the MPA) is banned. A number of artificial reefs designed to prevent trawling contribute to the enforcement of this regulation.

Within the MPA (including the two NTZs), habitats are mainly composed of Posidonia oceanica seagrass meadows, and sandy and rocky bottoms including coralgal banks, i.e. coralline biogenic constructions (coralligenous). Rockfish assemblages are typical of the north-western Mediterranean coast, and are characterized by the dominance of three families: the Labridae, the Sparidae and the Serranidae [60].

The local artisanal fishery is typical of the north-western Mediterranean. It operates on the continental shelf $(0-200 \mathrm{~m})$ with fishing areas being within a few hours' reach from the harbors. The activity is characterized by the use of a diversity of gear and techniques and the frequentation of multiple fishing grounds, depending on the biology and ecology of a variety of target species [61-63]. Six artisanal fishing and yachting harbors are located within the MPA: Carro, Sausset-les-Pins, Carry-le-Rouet, La Redonne, Méjean and Niolon (Fig. 1). The distance between harbors and their nearest NTZ ranges from $\sim 300$ to $\sim 7600 \mathrm{~m}$ (Table 2). The study fleet is composed of 27 fishing boat skippers (hereafter fishers). Three other fishers were not included because their activity is based exclusively on the little-practiced methods of 
long-line, sea-urchin and coral fishing. The average crew is 1.7 persons per boat (SD: 0.7). The fleet (boats ranging from $6 \mathrm{~m}$ to $15 \mathrm{~m}$ in length) uses mainly gillnets and trammelnets. Of the 27 fishers, only 24 are active year-round within the MPA and were therefore included in this study (Table 2).

\subsection{Data collection}

Two types of data were collected in this study. Fishing activity over the year was estimated from data collected from July 2009 to June 2010. During this period, 16 fishers (67\% of the studied fleet), representing the different fishing harbors, were interviewed at approximately 10-day intervals to collect information relative to their most recent fishing trips. The choice of gear, the species targeted and the fishing grounds were recorded for each fishing operation. A fishing trip usually encompasses several fishing operations. For this reason, 1721 fishing operations and 1048 fishing trips have been described (i.e., on average, 65.5 (SD: 39.6) fishing trips and 107.6 (SD: 77.4) fishing operations per fisher) over the course of the year. During the interviews, fishers plotted fishing net locations on a background map $\left(1: 50000 ; n^{\circ} 6767 ;[64]\right)$. Spatial information collected was then entered into a Geographical Information System (ArcGIS 9.3® ESRI software). Fishers often pointed out the same net locations, with the result that only 206 fishing spots were recorded for the 1721 fishing operations. Eight groups of target species were considered (Table 3), based on IFREMER Fisheries Information System references [65].

At the end of the sampling year, each fisher was interviewed using a semi-directed questionnaire in order to appraise their perception of the effects of the NTZs on their own activity, on the artisanal fishery in general and on the marine ecosystem (Table 4). Questions were asked to determine the frequency of fishing trips to the zone adjacent to the NTZs, and to discover if users would fish more frequently near the NTZs, if this were technically possible (e.g. if there was enough space to set their nets, taking into account the competition for space with other fishers). Fishers were also asked how they perceived the balance between the loss of fishing grounds consecutive to NTZ establishment and the benefits brought by NTZs (Table 4). Finally, fishers were asked to identify the two most important factors guiding their selection of a fishing spot. All the interviews were conducted by the same researcher in order to reduce interviewer-related bias.

\subsection{Data analysis}


The year-round monitoring of fishing activity allowed us to consider the data collected as being representative of the activity of each fisher. This activity was then characterized by calculating the proportion of fishing operations for each group of target species and for each fisher. Frequency of fishing operations in the zone adjacent to the NTZs was calculated for each fisher using the mean distance between the fishing spot and the closest NTZ (calculated with ET Geowizard $®$ software).

The zone adjacent to a NTZ (Fig. 1 and Table 1) is potentially influenced by spillover. The extension of this zone depends on the species being considered, the topography and the habitats of the site. The width of this zone was once evaluated to exceed $700 \mathrm{~m} \mathrm{[56]:} \mathrm{however,}$ the value of $500 \mathrm{~m}$ was adopted, as suggested by Harmelin-Vivien et al. [57]. Analysis of the data relating to a wider adjacent zone resulted in no changes (when using $750 \mathrm{~m}$ ) or minor changes (when using $1000 \mathrm{~m}$ ) (results not reported here). Fishers were classified into three categories depending on their frequency of fishing within the zone adjacent to the NTZs: i) never operating there (0\%), ii) occasionally operating (1-20\%) and iii) regularly operating near the NTZs ( $>20 \%$ ). The threshold of $20 \%$ was chosen based on the pattern of activity in the zone adjacent to the NTZs (data not reported here), which shows a conspicuous discontinuity at the approach of this value. These data ('observed frequencies') were compared with data obtained from the questionnaire ('declared frequencies').

Three groups of target species ('Mugilids', 'Congers' and 'Cuttlefish') were excluded from the analysis as they represent a negligible percentage of the fishing effort (Table 3). Two other groups ('Hakes' and 'Flatfish') were excluded from some analyses, firstly because habitats and fishing grounds for these soft-bottom species are located far from the shore (Table 3) and from the NTZs, so that any effect due to the NTZs is unlikely; and secondly, because the effects of NTZs have only been demonstrated, or only appear likely, for the 'Sparids and European seabass' group (hereafter 'Sparids'), the 'Mullets and 'fish soup' (hereafter 'Mullets') and the 'Rockfish, dentex and lobsters' (hereafter 'Rockfish') [6, 54-58].

How fishers perceive the effects NTZs have on their own activity was evaluated according to seven themes : (1) how NTZs affect artisanal fishery in general; (2) how NTZs affect the marine ecosystem; (3) the balance between loss of fishing grounds and NTZ benefits; (4) increased fishing interest near the NTZs; (5) declared and observed frequencies of fishing in the zone adjacent to the NTZs; (6) targeting of 'Sparids', 'Mullets' and 'Rockfish'; and (7) the seniority of fishers (number of years they have been fishing within the MPA). Possible answers were defined for each question (Table 4). 


\section{Results}

Overall, there was no negative perception of the effects of NTZs, with the exception of a slight impression that losses exceed benefits ( $\sim 6 \%$ of answers) (Table 5). Positive opinions dominated, with lower numbers of neutral perceptions. Unexpectedly, when fishers evaluated the effects of NTZs on their own activity, they seemed less convinced (50\% of neutral opinion) than when they were asked non-personal questions such as the general effects of NTZs on the fishery as a whole ( $\sim 88 \%$ positive), the effects on the ecosystem ( $\sim 69 \%$ positive) and the overall effects of NTZ creation ( $\sim 62 \%$ beneficial or balanced). Hardly any fishers expressed an interest in fishing more frequently near the NTZs, even when they regarded the NTZs as being beneficial. This apparently contradictory result is, nevertheless, consistent with the fact that NTZ proximity is never mentioned ( $0 \%$ of responses) when questions target the two most important factors involved in the choice of a fishing location, unlike personal experience (which is mentioned in $63 \%$ of responses), fish abundance ( $\sim 44 \%)$, presence of suitable habitats $(38 \%)$, harbor proximity $(\sim 31 \%)$ and weather $(\sim 13 \%)$.

The positive perception a fisher may have of NTZ effects on their own activity parallels their declared and observed frequentation of the zone adjacent to the NTZs: the closer they fish to the NTZs, the more positive is their perception (Fig. 2). This perception of NTZ effects on their own activity is linked to their seniority (Fig. 3), rather than to their age (data not reported). The ratio of neutral to positive perception increases clearly with the number of years they have spent fishing in the MPA: 1:5 for $<10$ years, 1:1 for 10-20 years and $4: 1$ for $>20$ years. This indicates that the less seniority they have, the more positive is their perception of the NTZs (Fig. 3). This is confirmed by the high frequency of fishing in the zone adjacent to the NTZs, which was observed for fishers with less seniority (Fig. 4). Despite some differences between declared data (interviews) and observed data (monitoring of fishing trips and operations), it is worth noting that general patterns of frequentation and especially of perception, are consistent (Fig. 2 and 4).

How fishers perceive the effects of NTZs (spillover) and how they frequent the adjacent zones may also depend on the group of species targeted (Fig. 5). The most commonly targeted group in the zone adjacent to the NTZs is 'Sparids' (targeted 'regularly' in $\sim 20 \%$ of responses), with few or no fishers regularly targeting 'Mullets' (less than $10 \%$ ) and 'Rockfish' $(0 \%)$ in these areas. Fishing close to the NTZs appears to be associated with 
positive NTZ perceptions only in the case of fishers who target 'Sparids'. The contrary appears to be true for fishers targeting 'Mullets' (Fig. 5).

\section{Discussion}

\subsection{Absence of negative perception}

In this study, the social acceptance of the MPA by artisanal fishers was evidenced through the absence of negative perceptions concerning the effects of the NTZs on fishers' own activity, on the overall artisanal fishery and on the marine ecosystem. For the two latter points, positive perceptions are largely dominant, with a single fisher considering that benefits due to the NTZs did not compensate for the loss of fishing grounds incurred when the NTZs were established. It is worth emphasizing that a neutral perception is all but neutral: there is no feeling of loss, even when fishers did not perceive benefits from the NTZs.

This high degree of social acceptance can be explained by the involvement of fishing guilds in the establishment and management of the PMCB, and by the cooperation with local scientists. This is a positive illustration of the wide consensus concerning the necessity to involve stakeholders in resource management [50, 53, 66-70]. It also underlines the successful communication by PMCB managers of both the direct and the indirect benefits of NTZs, and also concerning the MPA objectives, as observed in other places [34, 40, 71-72].

The age of both PMCB NTZs, Carry and Couronne (28 and 15 years respectively), may also be a determining factor in explaining the social acceptance of these areas by fishers. Acceptance takes time [34] and the effects of protection on resources are often dependent on the age (and the size) of the NTZs [14]; see also [73].

\subsection{Frequentation and targeted groups matter}

As shown above, fishers' positive perceptions of NTZ effects can be observed even if they themselves do not report any direct benefits to their own activity. Their perceptions may also be interesting as indicators of biomass exportation from NTZs. Differences in field strategies between scientists and fishers can result in differing evaluations of the NTZ effects, which should be seen as complementary [47, 49]. In this respect, the spillover demonstrated in proximity to the two NTZs of the PMCB [56-59] is partly corroborated by fishers' perceptions of NTZ effects on their own activity, depending on frequency of fishing in the 
zone adjacent to the NTZs. Although there is no clear-cut difference between neutral and positive perceptions regardless of the frequency of fishing in the zone adjacent to the NTZs, a degree of positivity seems to be associated with higher frequentation of the zone adjacent to the NTZs.

How fishers perceive the effects of NTZs on their own activity also depends on the target species. For the 'Sparids' group, positive perceptions seem to be linked to the frequency of fishing trips to the zone adjacent to NTZs and the same is true to a lesser extent for the 'Rockfish' group. This trend matches scientific expectations concerning spillover for these species. However, and more surprisingly, the reverse is observed for the 'Mullets', for which the effects of NTZs have been the most frequently noticed [56, 58-59].

\subsection{Mismatch between fishers' perceptions and scientific expectations}

For the 'Mullets' group, the mismatch between NTZ effects observed and fishers' perceptions may be due to the fact that these NTZ effects are not large enough to be noticed by fishers. The variability of catches, which is a general feature (Leleu, unpublished data), may conceal the widely recognized NTZ effects for this group. In addition, the species belonging to this group are small in size, which may further obscure the perception of NTZ effects on their size.

Another explanation may be that spillover around the NTZs is itself quite variable over time and space. This variability of catches near the NTZs may help explain fisher perceptions concerning 'Rockfish'. Fishers' declarations show that catches of large spiny lobsters (Palinurus elephas) or scorpion fish (Scorpaena scrofa) occasionally occurred near the NTZ, apparently sufficiently enough to be attributed to the NTZ -and thus to influence their perceptions- but not sufficiently enough to promote more frequent fishing within the zone adjacent to the NTZs.

Furthermore, it is possible that biomass export is not the only beneficial effect of NTZs that fishers take into account when considering potential effects on their own activity. Indeed, fishers often expect that NTZs both enhance fish diversity ([22] and references therein) and protect essential habitats for spawning [58, 74-76]. These benefits may be as important as biomass export in fishers' perceptions. This is a key point for 'Sparids' at the Couronne NTZ, which has been identified by both scientists and fishers as an important spawning ground for Dicentrarchus labrax (Frédéric Bachet, pers. comm.). Such effects may 
explain the positive perceptions of this NTZ by fishers who were never observed- or who were only occasionally observed- to fish in the zone adjacent to this NTZ.

The local history of the establishment of NTZs obviously has an influence on fishers' perceptions. Differences in gear deployed and in species targeted were already site-specific before the creation of the two NTZs. It is thus possible that NTZ effect and any compensation perceived as resulting from NTZ benefits may differ depending on the characteristics of the site chosen for the NTZ. The sites proposed and chosen for setting up NTZs are not always the best ones in terms of conservation and resource management, but rather, are often those that encounter the least opposition from users (in particular, fishers) [77]. Finally, the size (surface area) of the NTZs can be insufficient in terms of generation of noticeable spillover and in enabling fishers to perceive this spillover [8, 18, 78].

For these reasons, NTZs can be less productive than other fishing grounds within or outside the MPA. To the west, the PMCB MPA actually borders the Gulf of Fos and the Rhone River Delta, which are known to be productive areas [79]. Thus, even if fishers perceive positive NTZ effects, the difference with other productive sites might not be appreciable enough to induce them to change their fishing habits [29, 56, 80-81]. This could account for the unexpected negative reply of fishers to the question "Would you fish more frequently near the NTZ if it were technically possible?", and for the fact that proximity to the NTZs was said to never be involved in the choice of a fishing spot.

Redistribution of fishing effort after the establishment of NTZs [28], proximity to harbors [30, 80], existence of former fishing grounds around NTZs [56], as well as regulations governing access to the fishing zone [82-83] may all help explain neutral perceptions associated with fishing in the zone adjacent to NTZs. In addition, the concentration of effort around NTZ boundaries can lead to localized stock depletion, resulting in a potentially significant impact on the perception of biomass export when fishing near the NTZs [11-13, $30,84]$.

\subsection{Seniority: a key to perceptions?}

The number of years the fisher has been fishing within the MPA (seniority) largely explains their perceptions of the NTZ effects on their own activity. In this study, positive perceptions are inversely linked to seniority. In addition, fishers with less seniority seem to be more attracted by the zone adjacent to the NTZs than those with more seniority. Positive perceptions of NTZ effects on fishers' own activity, or fishing frequency in the zone adjacent 
to the NTZs may simply reflect a belief in the potentially beneficial effects of NTZs rather than merely the NTZ effects themselves $[12,75,80]$. However, positive perception may also reflect the fact that more experienced fishers are less inclined to change fishing grounds.

\section{Conclusion}

1. This study shows that in the Parc Marin de la Côte Bleue - an MPA with two wellestablished NTZs (created 28 and 15 years ago, respectively) - negative perceptions of the MPA by fishers are either nil or are negligible. Most fishers are aware of the beneficial effects of the NTZs on the fishery and ecosystem, effects which are corroborated by scientific studies. Surprisingly, fishers appear less convinced by the beneficial effects of NTZs on their own activity. Moreover, their responses indicate that they are not interested in fishing more frequently near the NTZs, and that NTZ proximity is never a consideration in their choice of a fishing spot. Positive perceptions of NTZ effects can therefore be associated with an absence of perception of potential personal benefit.

2. Several factors should be taken into account when analyzing fishers' perceptions, including frequency of activity to the zone adjacent to the NTZs, targeted fish groups and seniority. It appears likely that the lack of correspondence between scientific expectation and fishers' perceptions results from diverse causes such as natural variability of catches, insufficient surface area of the NTZs, lack of attractiveness due to insignificant differences between near and distant catches in relation to the NTZs, from the presence of other productive fishing grounds within or outside the MPA, in addition to several exogenous factors such as the social context.

3. Fishers' perceptions can be seen as an indicator of the degree of social acceptance of a MPA and provide as such an essential tool for monitoring MPA governance. This study illustrates how MPA acceptance improves when fishers are directly involved in MPA establishment and management. Perception studies may also help in the assessment of managerial communication strategy when promoting MPA performance and in the development of actions aimed at improving them. Our results underline the mismatches between scientific data and fishers' perceptions and thus indicate that the latter must not be seen as an alternative to resource assessment in the evaluation of MPA performance. Both approaches are clearly complementary.

4. Finally, even if scientific evidence might leave no doubt about spillover effects from NTZs, the same cannot be said of human perception. Indeed, individuals may be not able to perceive 
these effects. For this reason, the potential benefits of biomass export should be promoted with caution when creating MPAs: creating high expectations may lead to disappointment if benefits are not forthcoming. This, in turn, could lead to changes in perceptions and to a resulting degradation of social acceptance if MPA performance does not live up to stakeholders' expectations.

\section{Acknowledgment}

The authors would like to thank the prud'homies des pêcheurs of Marseille and Martigues for their collaboration, as well as all the fishers whose help made this study possible. They are grateful to Frédéric Bachet and to the team of the Parc Marin de la Côte Bleue for their precious assistance during the field survey. This study was part of two multidisciplinary research projects on governance and performance of MPAs, namely GAIUS (http://www.crhsete.org/projets/fiche_gaius.pdf) and PAMPA (http://wwz.ifremer.fr/pampa). It was funded in part by the research project GAIUS. Finally the authors are grateful to Rachel Mackie for correction of the English text, and to an anonymous reviewer.

\section{References}

[1] Roberts CM, Bohnsack JA, Gell F, Hawkins JP, Goodridge R. Effects of Marine Reserves on Adjacent Fisheries. Science. 2001;294:1920-3.

[2] Ward T, Hegerl E. Marine protected areas in ecosystem-based management of fisheries. Commonweath of Australia publ, Canberra. 2003:1-66.

[3] Sale PF, Cowen RK, Danilowicz BS, Jones GP, Kritzer JP, Lindeman KC, et al. Critical science gaps impede use of no-take fishery reserves. Trends in Ecology and Evolution. $2005 ; 20$.

[4] Boudouresque CF, Cadiou G, Diréach L. Marine Protected Areas: A Tool for Coastal Areas Management. In: Levner E, Linkov I, Proth J-M, editors. Strategic Management of Marine Ecosystems: Springer Netherlands; 2005. p. 29-52.

[5] Cadiou G, Boudouresque CF, Bonhomme P, Le Diréach L. The management of artisanal fishing within the Marine Protected Area of the Port-Cros National Park (northwest Mediterranean Sea): a success story? ICES Journal of Marine Science: Journal du Conseil. 2009;66:41-9. 
[6] Goñi R, Hilborn R, Diaz D, Mallol S, Adlerstein S. Net contribution of spillover from a marine reserve to fishery catches. Marine Ecology Progress Series. 2010;400:233-43.

[7] Jennings S. Patterns and prediction of population recovery in marine reserves. Reviews in Fish Biology and Fisheries. 2000;10:209-31.

[8] Halpern BS, Warner RR. Matching marine reserve design to reserve objectives.

Proceedings of the Royal Society of London Series B-Biological Sciences. 2003;270:1871-8.

[9] Russ GR, Alcala AC. Do marine reserves export adult fish biomass? Evidence from Apo Island, central Philippines. Marine Ecology Progress Series. 1996;132:1-9.

[10] Russ GR, Alcala AC, Maypa AP, Calumpong HP, White AT. Marine reserve benefits local fisheries. Ecological Applications. 2004;14(2):597-606.

[11] Goñi R, Quetglas A, Reñones O. Spillover of spiny lobsters Palinurus elephas from a marine reserve to an adjoining fishery. Marine Ecology Progress Series. 2006;308:207-19. [12] Kellner JB, Tetreault I, Gaines SD, Nisbet RM. Fishing the line near marine reserves in single and multispecies fisheries. Ecological Applications. 2007;17:1039-54.

[13] McClanahan TR, Mangi S. Spillover of exploitable fishes from a marine park and its effect on the adjacent fishery. Ecological Applications. 2000;10:1792-805.

[14] Claudet J, Osenberg CW, Benedetti-Cecchi L, Domenici P, García-Charton J-A, PérezRuzafa Á, et al. Marine reserves: size and age do matter. Ecology Letters. 2008;11:481-9. [15] Claudet J, Osenberg CW, Domenici P, Badalamenti F, Milazzo M, Falcon JM, et al. Marine reserves: Fish life history and ecological traits matter. Ecological Applications. 2010;20:830-9.

[16] García-Charton JA, Pérez-Ruzafa A, Sanchez-Jerez P, Bayle-Sempere J, Renones O, Moreno D. Multi-scale spatial heterogeneity, habitat structure, and the effect of marine reserves on Western Mediterranean rocky reef fish assemblages. Marine Biology. 2004;144:161-82.

[17] Meir E, Andelman S, Possingham HP. Does conservation planning matter in a dynamic and uncertain world? Ecology Letters. 2004;7:615-22.

[18] Avasthi A. California tries to connect its scattered marine reserves. Science. 2005;308:487-8.

[19] Kaplan DM. Alongshore advection and marine reserves: consequences for modeling and management. Marine Ecology Progress Series. 2006;309.

[20] Forcada A, Bayle-Sempere J, Valle C, Sanchez-Jerez P. Habitat continuity effects on gradients of fish biomass across marine protected area boundaries. Marine Environmental Research. 2008;66:536-47. 
[21] Seytre C, Francour P. Is the Cape Roux marine protected area (Saint-Raphaël, Mediterranean Sea) an efficient tool to sustain artisanal fisheries? First indications from visual censuses and trammel net sampling. Aquatic Living Resources. 2008;21:297-305.

[22] Pelletier D, García-Charton JA, Ferraris J, David G, Thébaud O, Letourneur Y, et al. Designing indicators for assessing the effects of marine protected areas on coral reef ecosystems: A multidisciplinary standpoint. Aquatic Living Resources. 2005;18:15-33. [23] Alcala AC, Russ GR, Maypa AP, Calumpong HP. A long-term, spatially replicated experimental test of the effect of marine reserves on local fish yields. Canadian Journal of Fisheries and Aquatic Sciences. 2005;62:98-108.

[24] Stobart B, Warwick R, Gonzalez C, Mallol S, Diaz D, Renones O, et al. Long-term and spillover effects of a marine protected area on an exploited fish community. Marine Ecology Progress Series. 2009;384:47-60.

[25] Guidetti P, Bussotti S, Pizzolante F, Ciccolella A. Assessing the potential of an artisanal fishing co-management in the Marine Protected Area of Torre Guaceto (southern Adriatic Sea, SE Italy). Fisheries Research. 2010;101:180-7.

[26] Salomon AK, Waller NP, McIlhagga C, Yung RL, Walters C. Modeling the trophic effects of marine protected area zoning policies: A case study. Aquatic Ecology. 2002;36:8595.

[27] Gell FR, Roberts CM. Benefits beyond boundaries: the fishery effects of marine reserves. Trends in Ecology and Evolution. 2003;18 No. 9:448-55.

[28] Halpern BS, Gaines SD, Warner RR. Confounding effects of the export of production and the displacement of fishing effort from marine reserves. Ecological Applications. 2004; 14:1248-56.

[29] Abesamis RA, Alcala AC, Russ GR. How much does the fishery at Apo Island benefit from spillover of adult fish from the adjacent marine reserve? Fishery bulletin. 2006;104:36075.

[30] Stelzenmüller V, Maynou F, Bernard G, Cadiou G, Camilleri M, Crec'hriou R, et al. Spatial assessment of fishing effort around European marine reserves: Implications for successful fisheries management. Marine Pollution Bulletin. 2008;56:2018-26.

[31] Francour P, Harmelin J-G, Pollard D, Sartoretto S. A review of marine protected areas in the northwestern Mediterranean region: siting, usage, zonation and management. Aquatic Conservation: Marine and Freshwater Ecosystems. 2001;11:155-88. 
[32] Roncin N, Alban F, Charbonnel E, Crec'hriou R, de la Cruz Modino R, Culioli J-M, et al. Uses of ecosystem services provided by MPAs: How much do they impact the local economy? A southern Europe perspective. Journal for Nature Conservation. 2008;16:256-70. [33] Suman D, Shivlani M, Walter Milon J. Perceptions and attitudes regarding marine reserves: a comparison of stakeholder groups in the Florida Keys National Marine Sanctuary. Ocean \& Coastal Management. 1999;42:1019-40.

[34] McClanahan T, Maina J, Davies J. Perceptions of resource users and managers towards fisheries management options in Kenyan coral reefs. Fisheries Management and Ecology. 2005;12:105-12.

[35] Alban F, Appéré G, Boncoeur J. Economic Analysis of Marine Protected Areas. A Litterature Review. EMPAFISH Project, Booklet n³. 2006.

[36] Himes AH. Performance indicators in MPA management: Using questionnaires to analyze stakeholder preferences. Ocean \& Coastal Management. 2007;50:329-51. [37] McClanahan TR, Cinner J, Kamukuru AT, Abunge C, Ndagala J. Management preferences, perceived benefits and conflicts among resource users and managers in the Mafia Island Marine Park, Tanzania. Environmental Conservation. 2008;35:340-50.

[38] Gelcich S, Godoy N, Castilla JC. Artisanal fishers' perceptions regarding coastal comanagement policies in Chile and their potentials to scale-up marine biodiversity conservation. Ocean \& Coastal Management. 2009;52:424-32.

[39] Gelcich S, Defeo O, Iribarne O, Del Carpio G, DuBois R, Horta S, et al. Marine ecosystem-based management in the Southern Cone of South America: Stakeholder perceptions and lessons for implementation. Marine Policy. 2009;33:801-6.

[40] Dimech M, Darmanin M, Philip Smith I, Kaiser MJ, Schembri PJ. Fishers' perception of a 35-year old exclusive Fisheries Management Zone. Biological Conservation. 2009;142:2691-702.

[41] Pita C, Pierce GJ, Theodossiou I. Stakeholders' participation in the fisheries management decision-making process: Fishers' perceptions of participation. Marine Policy. 2010;34:1093102.

[42] Neis B, Schneider DC, Felt R, Haedrich RL, Fischer J, Hutchings JA. Fisheries assessment: what can be learned from interviewing resource users? Canadian Journal of Fisheries and Aquatic Sciences. 1999;56:1949-63.

[43] Johannes RE, Freeman MMR, Hamilton RJ. Ignore fishers' knowledge and miss the boat. Fish and Fisheries. 2000;1:257-71. 
[44] Mackinson S. Integrating Local and Scientific Knowledge: An Example in Fisheries Science. Environmental Management. 2001;27:533-45.

[45] Grant S, Berkes F. Fisher knowledge as expert system: A case from the longline fishery of Grenada, the Eastern Caribbean. Fisheries Research. 2007;84:162-70.

[46] Haggan N, Neis B, Baird IG. Fishers' Knowledge in Fisheries Science and Management. Paris, FRANCE: UNESCO; 2007.

[47] Rochet M-J, Prigent M, Bertrand JA, Carpentier A, Coppin F, Delpech J-P, et al. Ecosystem trends: evidence for agreement between fishers' perceptions and scientific information. ICES Journal of Marine Science: Journal du Conseil. 2008;65:1057-68. [48] Agardy T, Bridgewater P, Crosby MP, Day J, Dayton PK, Kenchington R, et al. Dangerous targets? Unresolved issues and ideological clashes around marine protected areas. Aquatic Conservation: Marine and Freshwater Ecosystems. 2003;13:353-67.

[49] Mackinson S, van der Kooij J. Perceptions of fish distribution, abundance and behaviour: Observations revealed by alternative survey strategies made by scientific and fishing vessels. Fisheries Research. 2006;81:306-15.

[50] McClanahan T, Davies J, Maina J. Factors influencing resource users and managers' perceptions towards marine protected area management in Kenya. Environmental Conservation. 2005;32:42-9.

[51] Charles A, Wilson L. Human dimensions of Marine Protected Areas. ICES Journal of Marine Science: Journal du Conseil. 2009;66:6-15.

[52] Boltanski L, Thevenot L. De la justification. Les économies de la grandeur. Essais. Paris: Gallimard; 1991.

[53] Schumann S. Co-management and "consciousness"': Fishers' assimilation of management principles in Chile. Marine Policy. 2006;31:101-11.

[54] Planes S. (coordinator). Final report BIOMEX (Assessment of biomass export from marine protected areas and its impacts on fisheries in the Western Mediterranean Sea) Project - UE - QLRT-2001-0891. BIOMEX Perpignan.

Available at: http://biomex.univ-perp.fr/MEDIATEK/FinalReportBIOMEX.pdf. 2005. [55] Claudet J, Pelletier D, Jouvenel JY, Bachet F, Galzin R. Assessing the effects of marine protected area (MPA) on a reef fish assemblage in a northwestern Mediterranean marine reserve: Identifying community-based indicators. Biological conservation. 2006;130:349-69. [56] Goñi R, Adlerstein S, Alavrez-Berastegui D, Forcada A, Reñones O, Criquet G, et al. Spillover from six western Mediterranean marine protected areas: evidence from artisanal fisheries. Marine Ecology Progress Series. 2008;366:159-74. 
[57] Harmelin-Vivien M, Le Diréach L, Bayle-Sempere J, Charbonnel E, García-Charton JA, Ody D, et al. Gradients of abundance and biomass across reserve boundaries in six Mediterranean marine protected areas: Evidence of fish spillover? Biological conservation. 2008;141:1829-39.

[58] Forcada A, Valle C, Bonhomme P, Criquet G, Cadiou G, Lenfant P, et al. Effects of habitat on spillover from marine protected areas to artisanal fisheries. Marine Ecology Progress Series. 2009;379:197-211.

[59] Le Diréach L, Astruch P, Charbonnel E, Bonhomme D, Bachet F, Daniel B. Suivi des peuplements de poissons de la Réserve Marine du Cap Couronne (Parc Marin de la Côte Bleue) - Bilan 1995-2007. GIS /Posidonie - Parc Marin de la Côte Bleue, Fr. GIS Posidonie; 2010. p. $100 \mathrm{pp}+$ annexes.

[60] Harmelin JG. Structure et variabilité de l'icthiyofaune d'une zone rocheuse protégée en Méditerranée (Parc Nationale de Port Cros, France). PSZN. I: Marine Ecology. 1987;8:26384.

[61] Farrugio H, Le Corre G. A sampling strategy and methodology for assessment and monitoring of Mediterranean small-scale fisheries. Scientia Marina. 1993;57(2-3):131-7. [62] Colloca F, Crespi V, Cerasi S, Coppola SR. Structure and evolution of the artisanal fishery in a southern Italian coastal area. Fisheries Research. 2004;69:359-69.

[63] Forcada A, Valle C, Sánchez-Lizaso JL, Bayle-Sempere JT, Corsi F. Structure and spatio-temporal dynamics of artisanal fisheries around a Mediterranean marine protected area. ICES Journal of Marine Science: Journal du Conseil. 2010;67:191-203.

[64] Service Hydrographique et Océanographiques de la Marine. < http://www.shom.fr/>; [accessed 17 April 2011]. 2011.

[65] Institut Français de recherche pour l'exploitation de la mer. Système d'Informations Halieutiques < http://www.ifremer.fr/sih/>; [accessed 17 April 2011]. 2011.

[66] Jentoft S, McCay B. User participation in fisheries management: lessons drawn from international experiences. Marine Policy. 1995;19:227-46.

[67] Himes AH. Small-scale Sicilian fisheries: Opinions of artisanal fishers and sociocultural effects in two MPA case studies. Coastal Management. 2003;31:389-408.

[68] Webb EL, Maliao RJ, Siar SV. Using local user perceptions to evaluate outcomes of protected area management in the Sagay Marine Reserve, Philippines. Environmental Conservation. 2004;31:138-48. 
[69] Ferreira MNE, Freire NC. Community perceptions of four protected areas in the Northern portion of the Cerrado hotspot, Brazil. Environmental Conservation. 2009;36:12938.

[70] Launio CC, Morookaa Y, Aizakic H, Iigunia Y. Perceptions of small-scale fishermen on the value of marine resources and protected areas: case of Claveria, Northern Philippines. International Journal of Sustainable Development \& World Ecology. 2010;17:401-9. [71] Durand L. To think positive is not enough. Attitudes concerning conservation in the Sierra de Huautla Biosphere Reserve, Mexico. Interciencia. 2010;36:430-6.

[72] Cinti A, Shaw W, Torre J. Insights from the users to improve fisheries performance: Fishers' knowledge and attitudes on fisheries policies in Bahía de Kino, Gulf of California, Mexico. Marine Policy. 2010;34:1322-34.

[73] Halpern BS. The impact of marine reserves: Do reserves work and does reserve size matter? Ecological Applications. 2003;13:S117-S37.

[74] Beets J, Friedlander A. Evaluation of a conservation strategy: a spawning aggregation closure for red hind, Epinephelus guttatus, in the U.S. Virgin Islands. Environmental Biology of Fishes. 1999;55:91-8.

[75] Willis TJ, Millar RB, Babcock RC. Protection of exploited fish in temperate regions: high density and biomass of snapper Pagrus auratus (Sparidae) in northern New Zealand marine reserves. Journal of Applied Ecology. 2003;40:214-27.

[76] Boudouresque CF, Cadiou G, Le Diréach L. Marine Protected Areas : a tool for coastal areas management. Strategic Management of Marine Ecosystems. 2005:29-52.

[77] Roberts CM. Selecting marine reserve locations: optimality versus opportunism. Bulletin of Marine Science. 2000;66:581-92.

[78] Sala E, Aburto-Oropeza O, Paredes G, Parra I, Barrera JC, Dayton PK. A General Model for Designing Networks of Marine Reserves. Science. 2002;298:1991-3.

[79] Salen-Picard C, Arlhac D. Long-term changes in a Mediterranean benthic community: Relationships between the polychaete assemblages and hydrological variations of the Rhône River. Estuaries and Coasts. 2002;25:1121-30.

[80] Wilcox C, Pomeroy C. Do commercial fishers aggregate around marine reserves? Evidence from Big Creek Marine Ecological Reserve, central California. North American Journal of Fisheries Management. 2003;23:241-50.

[81] Salas S, Gaertner D. The behavioural dynamics of fishers: management implications. Fish and Fisheries. 2004;5:153-67. 
[82] Holland DS, Brazee RJ. Marine Reserves for Fisheries Management. Marine Resource Economics. 1996;11:157-71.

[83] Boncoeur J, Alban F, Thébaud O. Bioeconomic analysis of MPA fisheries effects. In:

Claudet J, editor. Marine Protected Areas: Effects, networks and monitoring - A

multidisciplinary approach. Cambridge, UK: Cambridge University Press; 2011. p. 226-246.

[84] Murawski SA, Wigley SE, Fogarty MJ, Rago PJ, Mountain DG. Effort distribution and catch patterns adjacent to temperate MPAs. ICES Journal of Marine Science: Journal du Conseil. 2005;62:1150-67. 


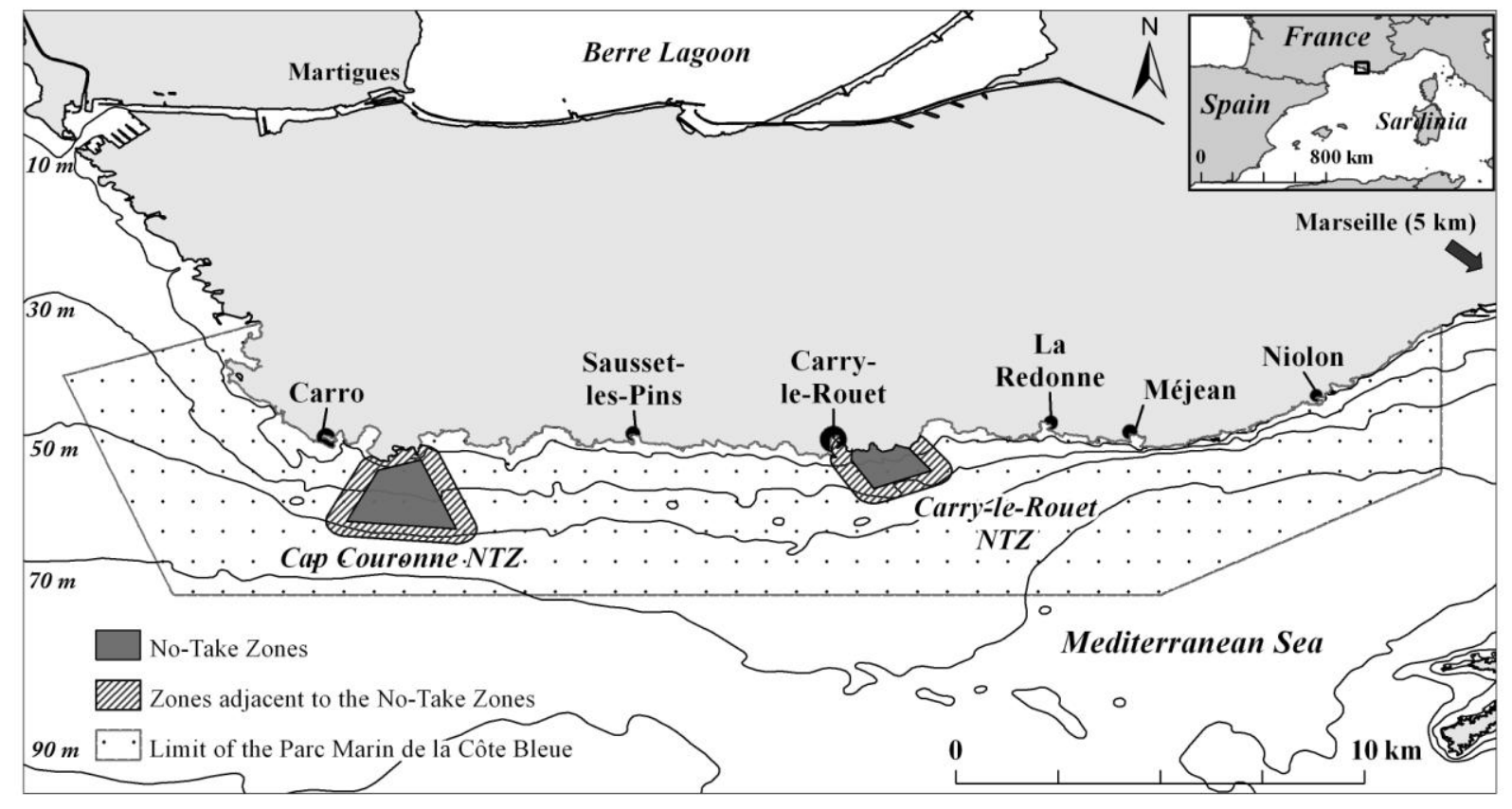

Figure 1. The study Marine Protected Area (MPA): Parc Marin de la Côte Bleue (PMCB).

Solid lines: depth contours.

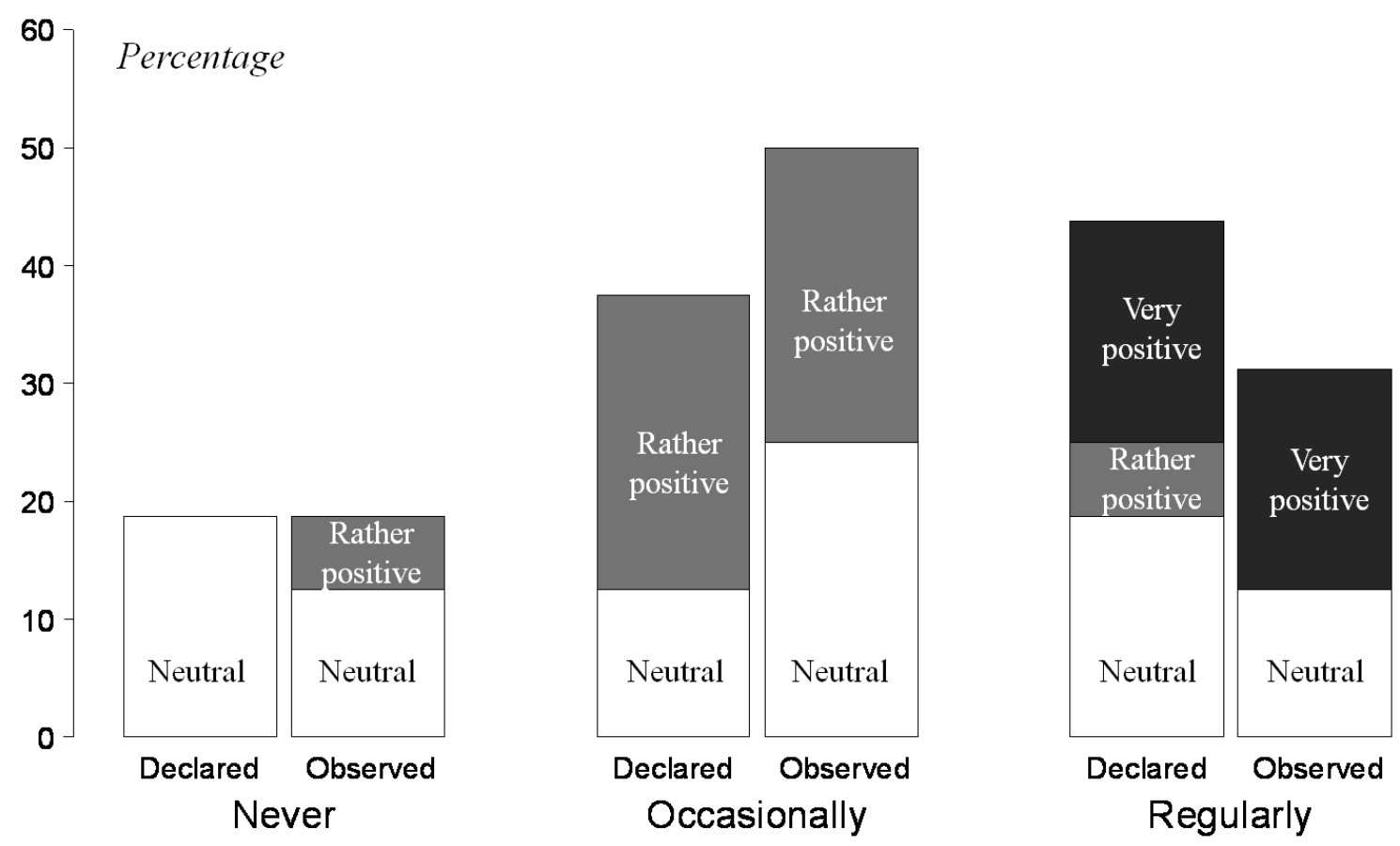

Figure 2. Declared and observed fishers' perceptions of no-take zone (NTZ) effects on their own activity, as a function of their frequency of fishing in the zone adjacent to the NTZs (never, occasionally or regularly). 


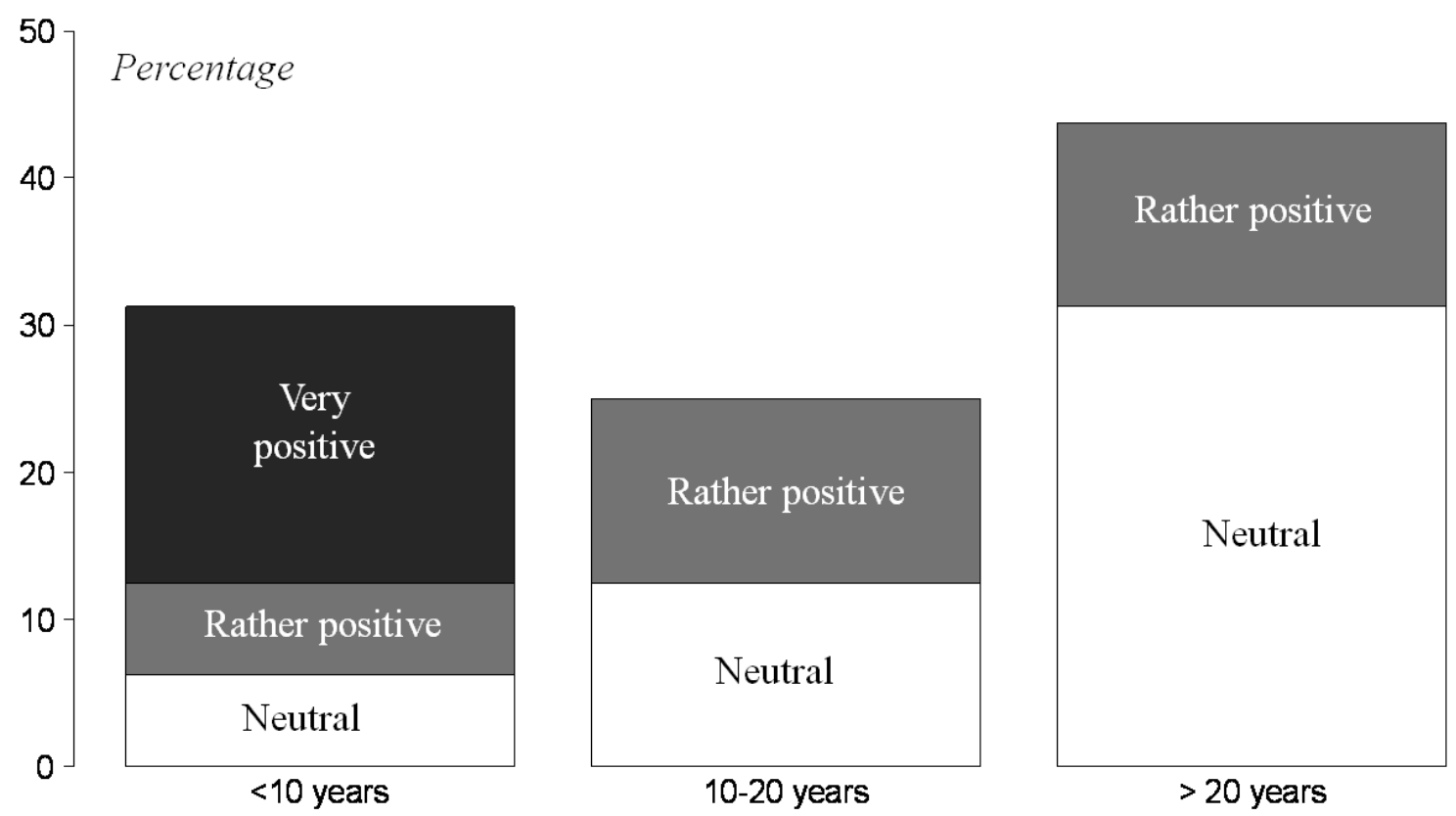

Figure 3. Fishers' perceptions of no-take zone effects on their own activity, as a function of their seniority (number of years since they started fishing as skippers in the MPA).

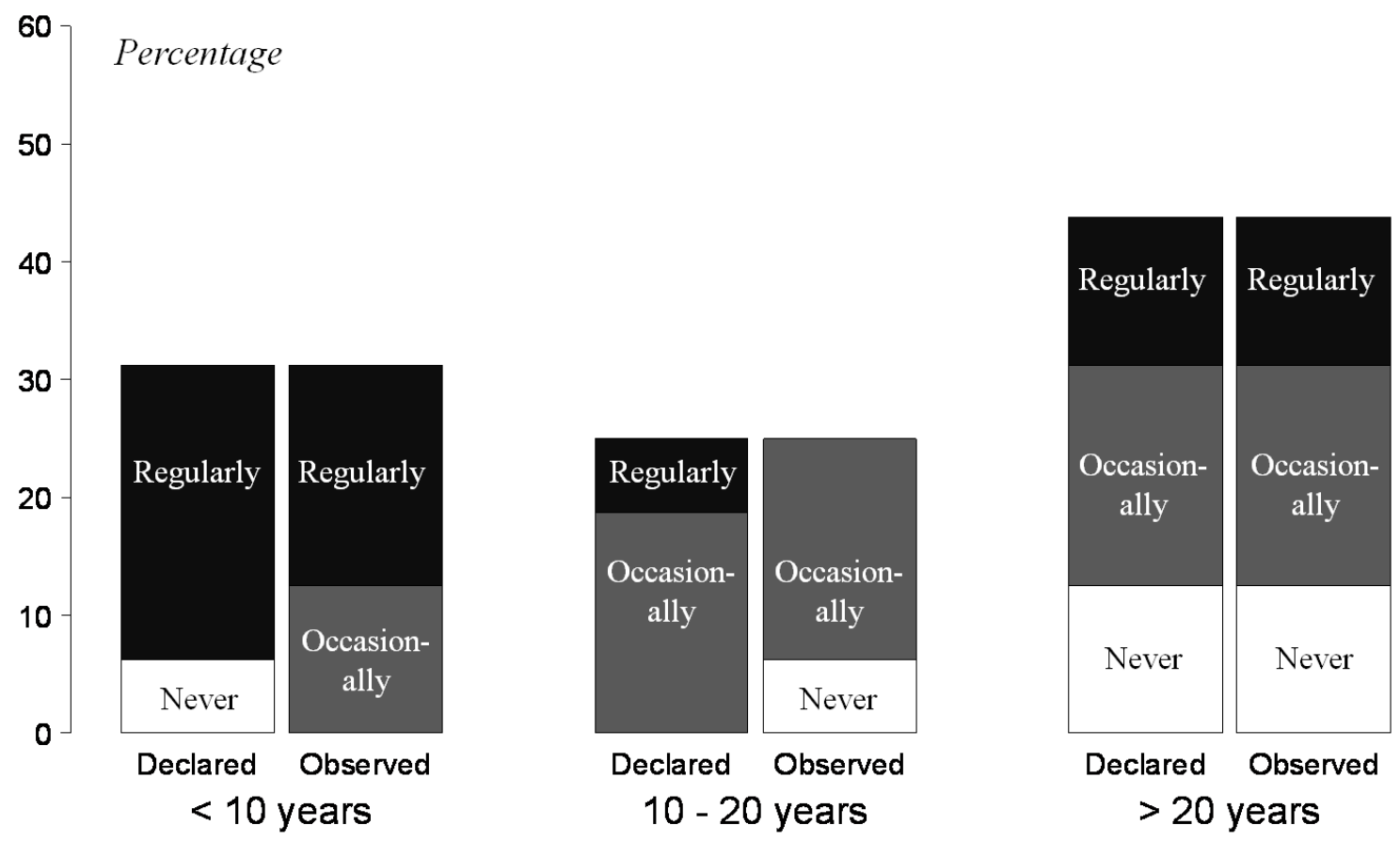

Figure 4. Fishers' frequency of fishing in the zone adjacent to the no-take zones (never, occasionally or regularly), as a function of their seniority (number of years since they started fishing as skippers in the MPA). Comparison between declared and observed percentages. 

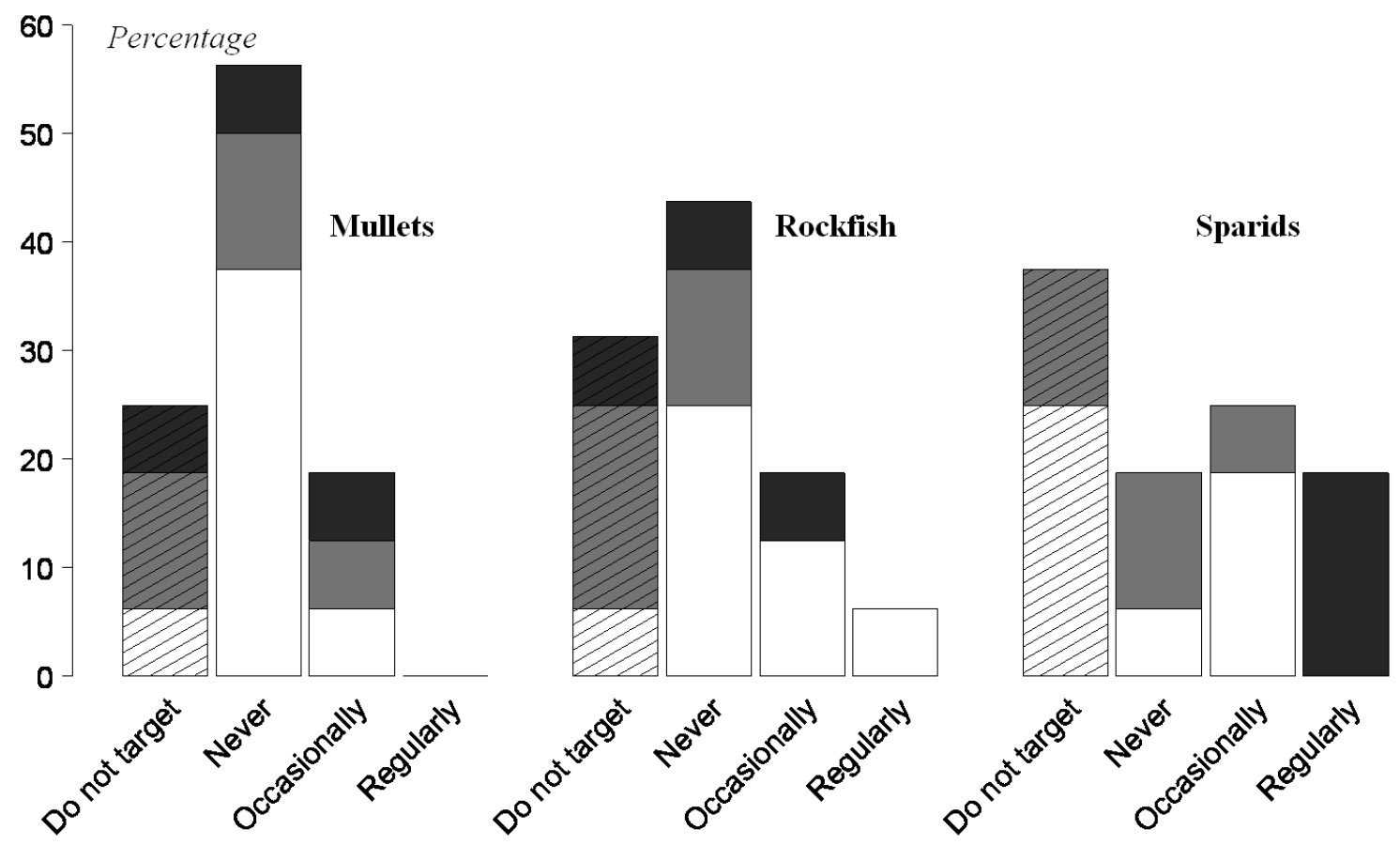

Figure 5. Fishers' perceptions of the no-take zone (NTZ) effects on their own activity, as a function of the groups of target species and of their observed frequentation of the zone adjacent to the NTZs. White: neutral; grey: rather positive; black: very positive. 
Table 1. Characteristics of the MPA no-take zones (NTZs) of the Parc Marin de la Côte Bleue MPA.

\begin{tabular}{|c|c|c|c|c|c|c|c|c|}
\hline $\begin{array}{l}\text { No-take } \\
\text { zones } \\
\text { (NTZs) }\end{array}$ & $\begin{array}{l}\text { Year of } \\
\text { establish- } \\
\text { ment }\end{array}$ & $\begin{array}{l}\text { Surface } \\
\text { area (ha) } \\
\text { and peri- } \\
\text { meter* } \\
\text { (m) }\end{array}$ & Main habitats & $\begin{array}{l}\text { Depth } \\
\text { range of } \\
\text { the NTZ } \\
\text { (m) }\end{array}$ & $\begin{array}{l}\text { Shortest and } \\
\text { greatest } \\
\text { distance } \\
\text { from the } \\
\text { shore (m) }\end{array}$ & $\begin{array}{l}\text { Surface } \\
\text { area of } \\
\text { the } \\
\text { adjacent } \\
\text { zones (ha) } \\
* *\end{array}$ & $\begin{array}{l}\text { Depth } \\
\text { range of } \\
\text { the } 500 \\
\mathrm{~m} \\
\text { adjacent } \\
\text { zones (m) }\end{array}$ & $\begin{array}{l}\text { Number } \\
\text { of boats } \\
\text { fishing } \\
\text { within the } \\
\text { adjacent } \\
\text { zones*** }\end{array}$ \\
\hline Couronne & 1996 & $\begin{array}{l}198 \\
5939\end{array}$ & $\begin{array}{l}\text { - Posidonia } \\
\text { oceanica seagrass } \\
\text { meadow }\end{array}$ & $10-50$ & $150-2000$ & 300 & $0-60$ & 10 \\
\hline Carry & 1983 & $\begin{array}{l}92 \\
2854\end{array}$ & $\begin{array}{l}\text { - Sandy bottoms } \\
\text { - Rocky bottoms } \\
\text { (including } \\
\text { coralgal banks) }\end{array}$ & $0-30$ & $0-910$ & 1165 & $0-40$ & 6 \\
\hline
\end{tabular}

* Perimeter is the length of the seaside limit of the NTZ

** Adjacent zone: a $500 \mathrm{~m}$ wide zone adjacent to the limit of the NTZ

*** Boats fishing year-round within the MPA, with at least one fishing trip in one of the adjacent zones of the NTZs 
Table 2. Main characteristics of the fishery of the Parc Marin de la Côte Bleue MPA.

\begin{tabular}{lll}
\hline Harbours & $\begin{array}{l}\text { Distance to the closest No-take } \\
\text { zone (NTZ) (NTZ concerned })\end{array}$ & $\begin{array}{l}\text { Number of skippers } \\
\text { (skippers fishing year- } \\
\text { round within the MPA)* }\end{array}$ \\
\hline Carro & $930 \mathrm{~m}($ Couronne $)$ & $15(13)$ \\
Sausset-les-Pins & $3800 \mathrm{~m}$ (Carry - Couronne $)$ & $4(4)$ \\
Carry-le-Rouet & $330 \mathrm{~m}($ Carry $)$ & $2(2)$ \\
La Redonne & $2375 \mathrm{~m}($ Carry $)$ & $3(3)$ \\
Méjean & $3900 \mathrm{~m}($ Carry $)$ & $2(2)$ \\
Niolon & $7575 \mathrm{~m}($ Carry $)$ & $1(0)$ \\
\hline
\end{tabular}

* Concerns only boats using gillnets and trammelnets. 
Table 3. Groups of species targeted within the Parc Marin de la Côte Bleue MPA, characterized by the gear used, the percentage of fishers concerned, the percentage of fishing operations and, for the five main groups, the mean distance of the fishing spots from the shore.

\begin{tabular}{|c|c|c|c|c|c|c|}
\hline $\begin{array}{l}\text { Groups of } \\
\text { target } \\
\text { species }\end{array}$ & $\begin{array}{l}\text { Main target } \\
\text { species }\end{array}$ & $\begin{array}{l}\text { Accessory target } \\
\text { species }\end{array}$ & Gear used & $\begin{array}{l}\text { Fishers } \\
\text { targeting } \\
\text { the group } \\
(\%)\end{array}$ & $\begin{array}{l}\text { Fishing } \\
\text { operations } \\
\text { targeting } \\
\text { the group } \\
(\%)\end{array}$ & $\begin{array}{l}\text { Mean } \\
\text { distance } \\
\text { of fishing } \\
\text { spots } \\
\text { from } \\
\text { shore (m) }\end{array}$ \\
\hline $\begin{array}{l}\text { Sparids } \\
\text { and } \\
\text { European } \\
\text { seabass }\end{array}$ & $\begin{array}{l}\text { Sparus aurata } \\
\text { Dicentrarchus } \\
\text { labrax }\end{array}$ & Diplodus spp. & $\begin{array}{l}\text { Gillnet } \\
\text { Trammelnet } \\
\text { Combined } \\
\text { net } \\
\text { Longline }\end{array}$ & 63 & 29.0 & 786 \\
\hline $\begin{array}{l}\text { Mullets } \\
\text { and 'Fish } \\
\text { soup'* }\end{array}$ & $\begin{array}{l}\text { Mullus } \\
\text { surmuletus } \\
\text { Mullus barbatus } \\
\text { Scorpaena notata } \\
\text { Scorpaena porcus } \\
\text { Serranus cabrilla } \\
\text { Serranus scriba } \\
\text { Symphodus spp. }\end{array}$ & & $\begin{array}{l}\text { Gillnet } \\
\text { Trammelnet }\end{array}$ & 69 & 22.4 & 699 \\
\hline
\end{tabular}

\begin{tabular}{|c|c|c|c|c|c|c|}
\hline $\begin{array}{l}\text { Rockfish, } \\
\text { dentex and } \\
\text { lobsters }\end{array}$ & $\begin{array}{l}\text { Scorpaena scrofa } \\
\text { Dentex dentex } \\
\text { Palinurus elephas }\end{array}$ & $\begin{array}{l}\text { Labrus merula } \\
\text { Labrus viridis }\end{array}$ & Trammelnet & 75 & 11.6 & 1669 \\
\hline Hakes & $\begin{array}{l}\text { Merluccius } \\
\text { merluccius }\end{array}$ & $\begin{array}{l}\text { Chelidonichthys } \\
\text { lucerna }\end{array}$ & Gillnet & 63 & 19.5 & 5594 \\
\hline Flatfish & $\begin{array}{l}\text { Solea solea } \\
\text { Solea aegyptiaca }\end{array}$ & $\begin{array}{l}\text { Psetta maxima } \\
\text { Scophthalmus } \\
\text { rhombus }\end{array}$ & Trammelnet & 69 & 16.3 & 3527 \\
\hline Mugilids & Mugilidae spp. & Diplodus spp. & Gillnet & 6 & 0.5 & \\
\hline
\end{tabular}




\begin{tabular}{lllll}
\hline Congers & Conger conger & Trap & 31 & 0.3 \\
& & Longline & \\
\hline Cuttlefish & Sepia officinalis & Trammelnet & 19 & 0.5 \\
& & & & \\
\hline
\end{tabular}

*'Fish soup' is the popular local name for a variety of small fishes which are ground to prepare a soup. 
Table 4. Questions asked during interviews with fishers (questionaire) and range of possible answers.

\begin{tabular}{|c|c|}
\hline Questions & Possible answers \\
\hline \multicolumn{2}{|l|}{ 1. How old are you? } \\
\hline $\begin{array}{l}\text { 2. How many years have you been fishing as } \\
\text { a skipper in the area? }\end{array}$ & $\begin{array}{l}\text { - Less than } 10 \text { years } \\
\text { - 10-20 years } \\
\text { - More than } 20 \text { years }\end{array}$ \\
\hline $\begin{array}{l}\text { 3. How often do you fish near the no-take } \\
\text { zones (NTZs)? }\end{array}$ & $\begin{array}{l}\text { - Regularly } \\
\text { - Occasionally } \\
\text { - Never } \\
\text { - Do not know }\end{array}$ \\
\hline $\begin{array}{l}\text { 4. What are the effects of the NTZs on your } \\
\text { own activity? }\end{array}$ & \multirow{3}{*}{$\begin{array}{ll}\left.\begin{array}{l}\text { - Very positive } \\
\text { - Rather positive }\end{array}\right\} & \rightarrow \text { Positive } \\
\left.\begin{array}{l}\text { - Neutral } \\
\text { - Rather negative } \\
\text { - Very negative }\end{array}\right\} & \rightarrow \text { Neutral } \\
- \text { Do not know } & \rightarrow \text { Negative } \\
& \rightarrow \text { Do not know }\end{array}$} \\
\hline $\begin{array}{l}\text { 5. What are the effects of the NTZs on the } \\
\text { artisanal fishery in general? }\end{array}$ & \\
\hline $\begin{array}{l}\text { 6. What are the effects of the NTZs on the } \\
\text { environment? }\end{array}$ & \\
\hline $\begin{array}{l}\text { 7. Do you think that the overall loss of } \\
\text { fishing grounds due to the establishment of } \\
\text { the NTZs has been: }\end{array}$ & $\begin{array}{l}\text { - More than compensated for by the positive } \\
\text { effects of the NTZs } \\
\text { - Compensated for by the positive effects of } \\
\text { the NTZs } \\
\text { - Not compensated for by the positive effects } \\
\text { of the NTZs }\end{array}$ \\
\hline $\begin{array}{l}\text { 8. Would you fish more frequently near the } \\
\text { NTZs if it were technically feasible? }\end{array}$ & $\begin{array}{l}- \text { Yes } \\
- \text { No } \\
\text { - Do not know }\end{array}$ \\
\hline $\begin{array}{l}\text { 9. What are the main two factors which } \\
\text { influence your selection of a fishing spot? }\end{array}$ & $\begin{array}{l}\text { - Fish abundance } \\
\text { - Suitable habitat } \\
\text { - NTZ proximity }\end{array}$ \\
\hline
\end{tabular}




\begin{tabular}{|l|l|}
\hline & - Artificial reefs \\
& - Regulations \\
& - Harbor proximity \\
& - Personal experience \\
& - No other, or few other fishers \\
\hline
\end{tabular}


Table 5. Fishers' perceptions of effects of no-take zones (NTZs) on the fishery and the ecosystem, expressed in percentage of answers. Columns give the percentage of answers to questions 4 through 8 , depending on how question 4 was answered.

4. NTZ effects on the fisher's own activity (\%)

\begin{tabular}{llcc|c}
\hline Positive & Neutral & Negative & $\begin{array}{c}\text { Do not } \\
\text { know }\end{array}$ & Total \\
& &
\end{tabular}

\begin{tabular}{|c|c|c|c|c|c|c|}
\hline 4. No-take & Positive & 50 & 0 & 0 & 0 & 50 \\
\hline zone (NTZ) & Neutral & 0 & 50 & 0 & 0 & 50 \\
\hline effects on the & Negative & 0 & 0 & 0 & 0 & 0 \\
\hline \multirow{2}{*}{$\begin{array}{l}\text { fisher's own } \\
\text { activity (\%) }\end{array}$} & Do not know & 0 & 0 & 0 & 0 & 0 \\
\hline & Total & 50 & 50 & 0 & 0 & 100 \\
\hline \multirow{5}{*}{$\begin{array}{l}\text { 5. NTZ effects } \\
\text { on artisanal } \\
\text { fishery (in } \\
\text { general) }(\%)\end{array}$} & Positive & 50 & 37.5 & 0 & 0 & 87.5 \\
\hline & Neutral & 0 & 12.5 & 0 & 0 & 12.5 \\
\hline & Negative & 0 & 0 & 0 & 0 & 0 \\
\hline & Do not know & 0 & 0 & 0 & 0 & 0 \\
\hline & Total & 50 & 50 & 0 & 0 & 100 \\
\hline \multirow{5}{*}{$\begin{array}{l}\text { 6. NTZ effects } \\
\text { on the } \\
\text { ecosystem (\%) }\end{array}$} & Positive & 31.3 & 37.5 & 0 & 0 & 68.8 \\
\hline & Neutral & 6.2 & 0 & 0 & 0 & 6.2 \\
\hline & Negative & 0 & 0 & 0 & 0 & 0 \\
\hline & Do not know & 12.5 & 12.5 & 0 & 0 & 25 \\
\hline & Total & 50 & 50 & 0 & 0 & 100 \\
\hline \multirow{5}{*}{$\begin{array}{l}\text { 7. Balance } \\
\text { between the } \\
\text { loss of fishing } \\
\text { grounds and } \\
\text { the benefits of } \\
\text { NTZs (\%) }\end{array}$} & Benefits & 31.3 & 12.5 & 0 & 0 & 43.8 \\
\hline & Balanced & 6.2 & 12.5 & 0 & 0 & 18.7 \\
\hline & Losses & 0 & 6.2 & 0 & 0 & 6.2 \\
\hline & Do not know & 12.5 & 18.8 & 0 & 0 & 31.3 \\
\hline & Total & 50 & 50 & 0 & 0 & 100 \\
\hline \multirow{4}{*}{$\begin{array}{l}\text { 8. Would you } \\
\text { fish more } \\
\text { frequently } \\
\text { near the NTZs } \\
\text { if this were } \\
\text { possible (\%) }\end{array}$} & Yes & 6.2 & 0 & 0 & 0 & 6.2 \\
\hline & No & 43.8 & 50 & 0 & 0 & 93.8 \\
\hline & Do not know & 0 & 0 & 0 & 0 & 0 \\
\hline & Total & 50 & 50 & 0 & 0 & 100 \\
\hline
\end{tabular}


